Research Institute of Animal Production Nitra', Slovakia and Institute of Genetics and Animal Breeding Jastrezebiec ${ }^{2}$, Poland

\author{
JÁN KMEŤ', TOMASZ SAKOWSKI², JÁN HUBA', DANA PEŠKOVIČOVA', \\ JOZEF CHRENEK ${ }^{1}$ and PETER POLÁK ${ }^{+}$
}

\title{
Application of Video Image Analysis in the slaughter value estimation of live Simmental bulls (short communication)
}

\begin{abstract}
Summary
A Video Image Analysis (VIA) was used for slaughter value analysis. The equipment was composed of a Cannon Stil Video Camera ION RC-260, IBM PC 486 DX, SVGA video card, V- Media Frame grabber and original software. The images were obtained from 63 dual- purpose Simmental bulls at the age of 15 months (536 kg live weight). Three images of each animal were taken from above, from the left side and from the rear. Twelve VIA- processed traits of body conformation, live weight and three characteristic of slaughter value indicators were correlated. Live weight before slaughter, cold carcass weight, weight of meat in carcass, weight of meat in valuable cuts were found to be highly correlated with the animals shoulder width, lumbar protuberance in the body width, body area from above, thigh rear area $(r=0.43-0.75)$. Certain body conformation characteristics with the highest correlation coefficient were used to construct a stepwise linear regression model for estimating the slaughter value of live bulls. The coefficients of determination of such a model were high $\left(\mathrm{R}^{2}=0.80-0.94\right)$ and showed the feasibility of using the method for predicting the slaughter value of live bull. It could also be applied as a selection criterion base on individual performance test. Other advantages of the method are its low cost and high speed of operation.
\end{abstract}

Key Words: bulls, Simmental, slaughter value, video image analysis

\section{Zusammenfassung}

Titel der Arbeit: Anwendung der Video Image Analyse bei der Schlachtkőrperwertschätzung von lebenden Bullen der Rasse Simmental (Kurzmitteilung)

Die Video Image Analyse (VIA) wurde fur die Schlachtkörperwertschätzung genutzt. Die apparative Ausstattung setzte sich aus einer Cannon Stil Video Kamera ION RC-260, IBM PC 486 DX, SVGA Video Karte, Rahmengreifer V-Media und Originalsoftware zusammen. Es wurden je drei Bilder von 63 Bullen der Rasse Simmental im Alter von 15 Monaten ( $\varnothing 536 \mathrm{~kg}$ Lebendmasse) aufgenommen und zwar vom ganzen Körper von oben, von der linken Seite und von hinten. Mittels der Video Image Analyse konnten zwölf Merkmale des Exterieurs, die Lebendmasse und drei charakteristische Merkmale des Schlachtkorperwertes, das Lebendgewicht vor dem Schlachten und das Schlachtgewicht (kalt) bearbeitet sowie die Beziehungen zwischen diesen Merkmalen untersucht werden. Fleischgewicht im Schlachtkörper und den wertvollen Fleischteilen waren hoch korreliert mit der Breite der Schulter. Ähnlich signifikante Beziehungen ergaben sich auch bei den ubrigen Merkmalen.

Die Bestimmtheitsmaße $\left(\mathrm{R}^{2}=0,80-0,94\right)$ ermøglichen eine Schătzung des Schlachtkorperwertes an lebenden Bullen. Dieses Modell könnte als Grundlage eines Selektionsmerkmales in der Eigenleistungsprufung von Bullen genutzt werden. Niedrige Kosten und Schnelligkeit des Verfahrens sind weitere Vorteile dieser Methode.

Schlusselwörter: Bullen, Simmentaler, Schlachtkörperwert, Video Image Analyse

\section{Introduction}

The estimation of in vivo body composition of live animals determined for slaughter or breeding respectively, a basic problem on all levels of the improving process of dual - 
purpose and beef cattle. Besides some exact and financialy very expensive methods, s.a. x-ray computer tomography (RCT), magnetic resonance imaging (MRI), or the method activity neutron (MAN), video image analysis (VIA) method became known chiefly for its mobility, cost accesibility and availability in operation conditions (KALLWEIT et al., 1994; SCHOLZ et al., 1995; BAULAIN et al., 1996, MITCHELL and SCHOLZ, 1997; BRANSCHEID and DOBROWOLSKI, 2000). Favourably obtained correlations of selected measures and slaughter characteristics were the impulse for this method realization. Therefore such solutions were searched for to make the process faster and sharper. First sharpening slaughter value by VIA method were accomplished by CROSS et al. (1983), MISZTAL et al. (1986) and JANKOWSKI et al. (1978). Technical deficiency, imperfect quality of view and little computer capacity for data archive were the reason for present practical unutilization. Today VIA is the fastest developing sector of informatic (MADSEN and THODBERG, 1994). SCHOLZ et al. (1996) and IRIE et. al. (1996) who experimentaley proved the given method by slaughter body classification $(R 2=0.63)$, monitoring of marbling and musculus longisimus dorsi surface $(\mathrm{R} 2=0.96)$ and meat water-holding capacity $\left(\mathrm{R}^{2}=0.94\right)$. The slaughter value estimation was dealt by BRANSCHEID et al. (1995), FERGUSON and THOMPSON (1995), SAKOWSKI and CYTOWSKI (1995), ALLEN and WALSTRA (1996) and BAULAIN et al. (1996).

\section{Material and Methods}

\section{Materials}

The images were prepared on dual - purpose Simmental bulls at the age of 15 months (approx. $536 \mathrm{~kg}$ live weight). Twelve characteristics of the body shape with the help of VIA processing and 3 characteristics of slaughter value were investigated. Based on 63 slaughtered bulls, hight significant correlations were found between carcass characteristic (LWS-live weight before slaughter, CCW-cold carcass weight, MCWweight of meat in carcass, WMVC-weight of meat in valuable cuts) and the following body measurements (SW-shoulder width, LPBW-lumbal protuberance in body width, BAA-body area from above, BSA-body shape area of the rear side).

\section{Video image analysis system}

Our research demanded the following equipment: Cannon Still Video Camera ION RC-260, IBM PC 486 DX, SVGA, Frame grabber and original Software. Three images of each animals were taken : first from the top of animal, second from the right side of the animal and third from the rear of the animal ( see pictures above). The images were digitized into TIFF standard and filtered afterwards. The filtering was processed by filter of contrast enhancement.

\section{Statistical analysis}

The analysis was accomplished in SAS 6.11 programme, using GLM procedure (SAS 1985) in Institute of Genetics and Animal Breeding, Jastrzębiec. For each investigated 
slaughter trait stepwice linear regression procedure was used to find most accurate linear regression model. Multiple correlation coefficients between every slaughter trait and vector of measurements were calculated. Using the best relations between slaughter trait and measurements on digitize image of animal the following overall stepwise regression linear model was constructed:

$$
Y_{i}-\bar{Y}=B_{1}\left(x_{1 i}-\bar{x}_{1}\right)+B_{2}\left(x_{2 i}-\bar{x}_{2}\right)+B_{3}\left(x_{3 i}-\bar{x}_{3}\right)+B_{4}\left(x_{4 i}-\bar{x}_{4}\right)+e_{i}
$$

$B_{1}, B_{2}, B_{3}, B_{4}-\quad$ regression coefficients on live weight before slaughter, shoulder

width, thurl-to-thurl width, body area from above

$\mathrm{x}_{1 \mathrm{i}}, \mathrm{x}_{2 \mathrm{i}}, \mathrm{x}_{3 \mathrm{i}}, \mathrm{x}_{4 \mathrm{i}}$ - $\quad$ live weight before slaughter, shoulder width, thurl-to-thurl width, body area from above, respectively

$\mathrm{Y}_{\mathrm{i}} \quad$ - vector of observation

$\mathrm{e}_{\mathrm{i}} \quad-\quad$ random error

Table 1

Means, standard deviations for carcass characteristics and the following body measurements made on digitized image of bulls (Mittelwerte und Standardabweichungen der untersuchten Merkmale der Bullen)

\begin{tabular}{lllrrrr}
\hline Trait & & $\mathrm{n}$ & \multicolumn{1}{c}{ Mean } & \multicolumn{1}{c}{ S.D. } & \multicolumn{1}{c}{ Min. } & \multicolumn{1}{c}{ Max. } \\
\hline LWS & $(\mathrm{kg})$ & 63 & 536.31 & 45.64 & 445.00 & 642.00 \\
CCW & $(\mathrm{kg})$ & 63 & 299.96 & 26.37 & 251.00 & 358.00 \\
MCW & $(\mathrm{kg})$ & 63 & 111.13 & 10.01 & 93.60 & 132.10 \\
WMVC & $(\mathrm{kg})$ & 63 & 60.86 & 5.40 & 49.60 & 71.90 \\
BAA & $\left(\mathrm{cm}^{2}\right)$ & 63 & 7577.07 & 745.79 & 5862.33 & 9302.88 \\
BSA & $\left(\mathrm{cm}^{2}\right)$ & 63 & 1739.79 & 306.00 & 1167.62 & 2991.84 \\
SW & $(\mathrm{cm})$ & 63 & 553.30 & 3.79 & 48.12 & 62.77 \\
LPBW & $(\mathrm{cm})$ & 63 & 55.85 & 3.17 & 48.08 & 61.63 \\
\hline
\end{tabular}

Table 2

Simple correlations between slaughter traits and some measurements on digitized image of bulls (Korrelationskoeffizienten zwischen Schlachtmerkmalen und ausgewăhlten Merkmalen aus der Video Image Analyse)

\begin{tabular}{lllll}
\hline Traits & SW & LPBV & BAA & BSA \\
\hline LWS & $0.67^{* *}$ & $0.69^{* *}$ & $0.70^{* *}$ & $0.54^{* *}$ \\
CCW & $0.75^{* *}$ & $0.74^{* *}$ & $0.70^{* *}$ & $0.45^{* *}$ \\
MCW & $0.65^{* *}$ & $0.63^{* *}$ & $0.61^{* *}$ & $0.43^{* *}$ \\
WMVC & $0.64^{* *}$ & $0.61^{* *}$ & $0.62^{* *}$ & $0.44^{* *}$ \\
\hline "o Significant variable $(\mathrm{P}<0.01)$ & & &
\end{tabular}

\section{Results and Discussion}

Means and standard deviations of various carcass and VIA- measured traits in Table 1 characterize the sample of 63 bulls. Four out of twelve investigated characteristics of body conformation of Simmental bulls were better correlated with meat productivity traits. Shoulder width, thurl-to-thurl width, top side profil area and the area of the right side of the rump measured on the animals were used for constructing a stepwise regression linear model. These traits showed high correlation with traits meat quality (Table 2) and also between themselves (Table 3 and Table 4). The most significant 
Table 3

The best simple correlations among body measurements on digitized image of bulls (Ausgewahlte hohe Korrelationskoeffizienten zwischen Merkmalen der Video Image Analyse)

\begin{tabular}{lccl}
\hline Variable & LPBW & BAA & BSA \\
\hline SW & $0.75^{\text {** }}$ & $0.82^{* *}$ & 0.21 \\
LPBW & - & $0.79^{* *}$ & $0.50^{* *}$ \\
BAA & & - & $0.42^{* *}$ \\
\hline
\end{tabular}

Table 4

The best simple correlations among slaughter traits on investigated bulls (Ausgewăhlte hohe Korrelationskoeffizienten zwischen Schlachtmerkmalen der untersuchten Bullen)

\begin{tabular}{lccc}
\hline Traits & CCW & MCW & WMVC \\
\hline LWS & $0.91^{\text {草 }}$ & $0.85^{\text {草 }}$ & 0.78 \\
CCW & - & $0.91^{* *}$ & 0.87 \\
MCW & & - & 0.95 \\
\hline
\end{tabular}

influence on prediction of slaughter value traits in live Simmental bulls has been considered for body weight of animal before slaughtering (0.01), cold carcass weight and shoulder width $(0.05)$. The rest of investigated characteristics, included in the model, increased also its accuracy. The body weight before slaughter, thurl-to-thurl width and shoulder width belong to those, which are relatively easy to investigate. Based on results of our research the most accurate linear regresion model for predicting of cold carcass weight was constructed:

$$
\begin{gathered}
\mathrm{CCW}=-54.82+0.43 \mathrm{LWS}+1.78 \mathrm{SW}+1.08 \mathrm{LPBV}+0.74 \mathrm{BAA} \\
\left(\mathrm{R}^{2}=0.94, \text { C.v. }=4.30\right)
\end{gathered}
$$

With the regard to strong relation of CCW to SW and LPBV it is possible to exclude BAA characteristic from our model. Then the regression equation will have the following form:

$$
\begin{gathered}
\mathrm{CCW}=-40.72+0.42 \mathrm{LWS}+1.37 \mathrm{SW}+0.74 \mathrm{LPBV} \\
\left(\mathrm{R}^{2}=0.93, \text { C.v. }=4.30\right)
\end{gathered}
$$

Similar relationships were considered also for predicting models of carcass weight and weight of the valuable cuts. Coefficient of determination was $R^{2}=0.94$ C.v. $=3.23$ for CCW, $\mathrm{R}^{2}=0.86$ C.v. $=4.89$ for lean content in carcass sides $\mathrm{R}^{2}=0.80 \mathrm{Cv}=3.01$ (Table 5).

Table 5

Partial linear regression coefficients for calculating of slaughter value traits on the digitized image measurements on live animal (Partielle lineare Regressionskoeffizienten für die Schătzung des Schlachtkörperwertes an lebenden Bullen mit Hilfe der Video Image Analyse)

\begin{tabular}{llllcccc}
\hline Trait & Intercept & LWS & SW & LPBW & BAA & R & C.v. \\
\hline CCW & -40.72 & 0.42 & 1.37 & 0.74 & - & 0.93 & 4.36 \\
CCW & -54.82 & 0.43 & 1.78 & 1.08 & -0.0040 & 0.94 & 3.24 \\
MCW & -0.94 & 0.17 & 0.58 & - & -0.0020 & 0.85 & 3.11 \\
MCW & -4.20 & 0.17 & 0.55 & 0.15 & -0.0020 & 0.86 & 4.89 \\
WMVC & 2.62 & 0.07 & 0.28 & 0.06 & - & 0.80 & 3.01 \\
WMVC & 2.31 & 0.07 & 0.29 & 0.06 & -0.0001 & 0.80 & 5.62 \\
\hline
\end{tabular}


Similar results also reached JANKOWSKI et al. (1978) $\mathrm{R}^{2}=0.48-0.94$ and MISZTAL (1975) $\mathrm{R}^{2}=0.86-0.91$ and SAKOWSKI and CYTOWSKI (1995). Based on our results and the results of SAKOWSKI and CYTOWSKI (1995), who developed the linear regression model for Holstein bulls, we suppose that the change of the animal production type will cause also the change of significant characteristics of body measurements on digitized image of the animal creating partial regression linear models. It is probably result from the different body conformation of each breed of bulls.

\section{References}

ALLEN, P.; WALSTRA,P.:

Non-invasive techniques for carcass assessement - grading applications. 47th Annual Meeting of the EAAP. Lillehammer, Norway, 1996, Session P-S VI.2

BAULAIN, U.; HENNING, M.; KALLWEIT, E.:

Bestimmung der Körperzusammensetzung von Landrasse-Schweinen unterschiedlichen Alters mittels MRI. Arch. Tierz., Dummerstorf 39 (1996) 4, 431-440

BRANSCHEID, W.; DOBROWOLSKI, A.; HÖRETH, R.:

Die Video Image Analyse. Methode zur online - Erfassung des Teilstilckwertes von Schweineschlachtkörpern. Fleischwirtschaft 75 (1995), $636-643$

BRANSCHEID, W.; DOBROWOLSKI, A.:

Evaluation of market value: comparison between different techniques applied on pork carcasses. Arch. Tierz., Dummerstorf 43 (2000) 2, 131-137

CROSS, H.R.; GILLILAND, A.D.: Beef carcass evaluation by use of video image analysis system. J. Anim. Sci., Albany, N.Y. 57 (1983), 908 - 917

FERGUSSON, D.M.; THOMPSON, J.M.: Prediction of beef carcass yield using whole carcass VIASCAN. Proc. 41'st ICoMST, 1995, Texas, USA, 189 - ?

IRIE, M.; IZUMO, A.; MOHRIS, S.:

Rapid Method for Determing Water-holding Capacity in Meat Using VIA and Simple Formule. Meat Sci. 42 (1996), 95 - ?

JANKOWSKI,W.; REKLEWSKI, Z.; DE LAURANSA, A.; GALKA, E.:

Results of the estimation of slaughter value in live cattle. (Polish Language) Pr. Mat. Zoot. 16 (1978), 33 $-50$

KALLWEIT, E.; WESEMEIER, H.H.; SMIDT, D.; BAULAIN, U.:

Einsatz der Magnet-Resonanz-Messung in der Tierzuchtforschung. Arch. Tierz,, Dummerstorf 37 (1994) 2, 105-120

MADSEN, N.T.; THODBERG, H.H.:

Application of $\mathrm{Via}$ and neutral networks in objective classification and prediction of carcass composition Proc. 40th ICoMST, 1994, Hague, The Netherlands

MISZTAL, I.:

Estimation of carcass composition in live cattle using picture processing system. Rocz. Nauk zoot. 13 (1989), 9 - 15

MITCHELL, A.D.; SCHOLZ, A.:

Dual-energy x-ray absorptiometry (DXA) analysis of growth and composition of pigs of different ryanodine receptor genotypes. Arch. Tierz., Dummerstorf 40 (1997) 1, 47-56

SAKOWSKI, T.; CYTOWSKI, J.: Application of Digital Image Processing in the slaughter value estimation of live bulls. Pr. Mat. Zoot. 5 (1995), $61-70$

SCHOLZ, A.; MITCHELL, A.D:, WANG, P.C.; SOPNG, H.; YAN, Z.:

Muscle metabolism and body composition of pigs with different ryanodine receptor genotypes studied by means of ${ }^{31} \mathrm{P}$ nuclear magnetic resonance spectroscopy and ${ }^{1} \mathrm{H}$ magnetic resonance imaging. Arch. Tierz., Dummerstorf 38 (1995) 5, 539-552 
SCHOLZ, A.; PAULKE, T.; EGER, H.:

Use of computer-supported video picture analysis. Fleischwirtschaft International 1 (1996), 9 - 14

Received: 1998-04-22

Accepted: $2000-04-18$

Authors' addresses

Ing. JÁN KMET̃, Ing. JÁN HUBA, Csc., Doc. Ing. JOZEF CHRENEK, Csc.,

Mgr. DANA PEŠKOVIČOVA, Ing. PETER POLÁK

Research Institute of Animal Production

Hlohovská 2

94992 Nitra

Slovakia

E-Mail: slach@vuzv.sk

Dr. TOMASZ SAKOWSKI

Institute of Genetics and Animal Breeding

Jastrezębiec

05-551 Mrokow

Poland 